\title{
Agricultural Development Programme (ADP) Capacity Building and Cassava Farmers Productivity in Anambra State
}

\author{
Obiadi, Adaobi J. ${ }^{1}$, Nwankwo, Frank O. ${ }^{1} \&$ Ezeokafor, Uche R. ${ }^{2}$ \\ ${ }^{1}$ Department of Cooperative Economics and Management, NnamdiAzikiwe University, Awka, Anambra State. \\ Nigeria \\ ${ }^{2}$ Department of Entrepreneurship Studies, ChukwuemekaOdumegwuOjukwu University, Igbariam Anambra State, \\ Nigeria \\ Correspondence: Ezeokafor, Uche R., Department of Entrepreneurship Studies, ChukwuemekaOdumegwuOjukwu \\ University, Igbariam Anambra State, Nigeria. E-mail: etiwistic@gmail.com
}

Received: December 20, 2020

Accepted: January 30, 2020

Online Published: January 31, 2020

doi:10.5430/bmr.v8n4p43

URL: https://doi.org/10.5430/bmr.v8n4p43

\begin{abstract}
This study was necessitated as a result of the low productivity of cassava farmers in Anambra State. The study set out to examine the effect of Agricultural Development Program (ADP) capacity building on cassava farmers' productivity in Anambra State. The work was anchored on Cobb-Douglas production model. Descriptive survey research design was adopted for the study. The population of this study comprised of all the ADP cassava farmers and non-ADP cassava farmers in Otuocha and Onitsha Agricultural Zone. With membership strength of three hundred and sixty (360) ADP Cassava farmers and one hundred and sixty (160) non-ADP cassava farmers, making up a total of five hundred and twenty (520) respondents. Structured and unstructured questionnaires were used for data collection and the analysis was done with Analysis of Variance (ANOVA) at 5\% level of significance. From the analysis showed that there is a significant difference in the output of ADPCFs and non ADPCFs in Anambra State (F=13.209 and p-value $<.05$ ). Based on the findings, the study concluded that belonging to ADP was responsible for the differences in output observed in the study. Sequel to this, it was recommended that cassava farmers in the state that are yet to key into ADP needs to do so in order to learn from the various level of capacity development programs organized by the body.
\end{abstract}

Keywords: Agricultural development, farmers' productivity, capacity building, cassava production, poverty reduction, food security

\section{Introduction}

Identification of the development constraints in the agricultural sector is a necessary step to unlock the factors inhibiting performance of the sector toward designing policy strategies that would create conducive climate for promoting accelerated commercialization and growth of the sector (Olukunle, 2013). The Agricultural Development Programme (ADP) was first launched in 1972 only two years after the end of civil war, when Nigeria was facing its first food and fibre deficiencies. The two main objectives of the ADP were to increase food production, and to raise the income of small-scale farmers through capacity building.

Capacity Building is the "process of equipping individuals with the understanding, skills, and access to information, knowledge, and training that enables them to perform effectively" in an informed society (Berg, 2016). The nature of ADP Capacity Building include training, apprenticeship, seminars, workshop and formal education (Okolo, 2011).

Among the crop varieties in Anambra State, ADP focused attention on cassava farmers because cassava production has many advantages over other crops; (i) It is a dominant crop in Anambra State, (ii) there is no cultural restriction on cassava production in Anambra State, (iii) the renewed international interest in the cassava crop as a source of biofuels (ethanol) has raised the importance of the crop, and (iv) Nigeria has potential comparative advantage (ability to produce at lower opportunity cost than others) in cassava production (Ayoola, 2013).

The specific objectives of ADP on cassava farming are to improve extension outreach to rural farmers; to train and encourage cassava farmers to adopt and use improved technologies in agricultural production, processing and utilization; to source and develop through research sustainable recommendation of technologies for activities solely performed by farmers; to train the farmers in income generating activities by facilitating and motivating the farmers to 
form cooperative groups to strengthen and enable them acquire productive skills; to liaise and collaborate with national, and international organizations that have programmes for farmers (World Bank, 2014).

Cassava products are very critical in the sustenance of the livelihood and income of a large proportion of rural farmers and households as well as ensuring the food needs of urban population. However, the challenges associated with the ability of the cassava farmers to reach the markets are quite discouraging. Intensifying the ability of cassava farmers to reach markets and actively participate in markets is a very big challenge affecting production of cassava products in Anambra State. Generally, the cassava farmers who have surplus goods have to sell them in unregulated markets. They do not, therefore, realize fair and reasonable price for their products. It is on the basis of this and others that this study set out toascertain the nature of ADP Capacity building activities of cassava farmers in the study area; and to compare the differences in output of ADP and non-ADP cassava farmers in the study area.

\subsection{Hypothesis}

$\mathbf{H o}_{1}$ : There is no significant differences between ADP and non-ADP cassava farmers output.

$\mathbf{H}_{1}$ : There is significant differences between ADP and non-ADP cassava farmers output.

\section{Conceptual Review}

\subsection{Capacity Building}

United Nations (2014) defines capacity building as a conceptual approach to development that focuses on understanding the obstacles that inhibit people, governments, international organizations and non-governmental organizations from realizing their developmental goals while enhancing the abilities that will allow them to achieve measurable and sustainable results. The term is also referred as capacity development.

The term community capacity building emerged in the lexicon of international development during the 1990s. Today, "community capacity building" is included in the programs of most international organizations that work in development, the World Bank, the United Nations (UN) and non-governmental organizations (NGOs). Wide usage of the term has resulted in controversy over its true meaning. Community capacity building often refers to strengthening the skills, competencies and abilities of people and communities in developing societies so they can overcome the causes of their exclusion and suffering (United Nations, 2016).

Capacity building (or capacity development) is also the process by which individuals and organizations obtain, improve, and retain the skills, knowledge, tools, equipment and other resources needed to do their jobs competently or to a greater capacity (Nwankwo, 2018).Capacity-building on an individual level requires the development of conditions that allow individual participants to build and enhance existing knowledge and skills. It also calls for the establishment of conditions that will allow individuals to engage in the "process of learning and adapting to change". Thus, capacity building is an evidence-driven process of strengthening the abilities of individuals, organizations, and systems to perform core functions sustainably, and to continue to improve and develop over time (Echeta, 2016).

\subsection{ADP Capacity Building}

Capacity building is integral to the cassava farmers' efforts to increase production (output). ADP Capacity building on the cassava farmers output is to strengthen the skills, competencies and abilities of cassava farmers in cassava farming, increase productivity and income so they can overcome the causes of their exclusion and suffering. ADP has a successful history of developing programs and training farmers around Nigeria. ADP and Ministry of Agriculture are working as a team to take Agriculture to greater height. ADP capacity building projects are designed to improve the abilities, skills and expertise of farmers. They also endeavour to design practical competency programs that are customized to meet the specific needs of each famer. They curriculum development focuses on the increase agricultural output (Nnadi, 2011).

ADP programs and training are for people in various areas of agriculture in order to get them prepared for the great task in increasing agricultural output. Farmers are expected to pass on what they have learnt in their training to others to practice for more efficiency. The essence of ADP capacity building to the farmers is to prepare farmers for abundant harvest, give them the opportunity to know and learn the new/best method of farming, reduce the cost of production of any seed, and prepare them for any eventualities (Okafor, 2011).

\subsection{Production (Output)}

Production is a process of combining various material inputs and immaterial inputs (plans, know-how) in order to make something for consumption (the output). Production is the same as output. It is physical produce and can be reported in units of volume or weight. Kamajou (2014) defined production as the output of goods and services coming 
from the production (manufacturing) process. Production has also been defined as the rate at which resources (inputs) are transformed into products. It is the act of creating a product, a good or service which has value and contributes to the utility of individuals. Agricultural production is the process of transforming agricultural resources into a form that will give us maximum satisfaction. Agricultural production decisions are, in effect decision making in the allocation of scarce resources (Uzor, 2015).

The production process is concerned with transforming a range of inputs into those outputs that are required by the market. This involves two main sets of resources - the transforming resources, and the transformed resources. Any production process involves a series of links in a production chain. High productivity means that a large amount of output is produced with little input. Some of the important factors of production are: Land, Labour, Capital, and Entrepreneur. Whatever is used in producing a commodity is called its inputs. For example, for producing cassava, a farmer uses inputs like soil, tractor, tools, seeds, manure, water and his own services. Cassava grows everywhere as long as it's giving what it takes to yield, adding that a virgin land is what is most needed for its cultivation (Rasheed, 2014).

\subsection{Cassava Farming}

The term usually applies to people who do some combination of raising field crops, orchards, vineyards, poultry, or other livestock. Peasant farmers tend towards cultivation of crops that require very little investment during their gestation periods. A popular example of such crop is cassava, which has become a very important crop in Nigerian agriculture. Cassava farmers are farmers that engaged in cultivation of cassava for food or raw materials. A cassava farmer's main goal is to produce a good cassava in order to make a living and to feed the population (Joachin, 2010).

All production of the crop (cassava) is hitherto consumed locally but the recent discovery of its potential as a foreign exchange earner, has led to strident calls to increase its cultivation. The resource-poor peasant cassava farmers are responsible for the expected boost in cassava production so that there can be enough for both domestic consumption and exportation to generate foreign exchange. Though the responsibility of increased production of cassava placed at the door-step of the peasant cassava farmers is to go along with increased soft loans from institutional sources, not many cassava farmers have been able to access the loans for some reasons. The most important of these reasons is the fact that the volume of credit available is limited relative to the number of loan seekers in the various subsectors of agriculture.

\subsection{Agriculture and Poverty Reduction in Nigeria}

Nwosu (2014) observed that there is a strong relationship between agricultural output, hunger and poverty, and that three quarters of the world's poor people live in the rural areas and make their living from agriculture. In addition, they noted that rates of poverty reduction have been very closely related to agricultural performance particularly the rate of growth of productivity. According to them, this indicates that countries that have increased their agricultural productivity the most have also achieved the greatest reductions in poverty. According to Fan and Rosegrant, (2014), Etim and Ukoha (2016), investing in agriculture is a key to reducing poverty and hunger in developing countries (such as Nigeria) and is an essential element in addressing the current food price crisis.

\subsection{Agricultural Growth and Food Security in Nigeria}

According to Senauer (2016), the essential components of an agricultural growth strategy are the technical change that increases output and cuts production costs, investment in rural infrastructure such as roads, irrigation, and widespread participation by small peasant producers including women farmers. Food security on the other hand, means assuring availability and access to sufficient quantities of food for all including the poor. Food security is the ability of a country or region to assure on long term basis that its food system provides the total population access to a timely, reliable and nutritionally adequate supply of food.

Wheeler (2017) observed that most people are hungry because they lack incomes to buy food, and suggested that to reduce significantly the number of hungry people, the strategy adopted should focus on agricultural growth and employment creation. He argued that since a large proportion of national income is generated by agriculture related employment, any strategy to increase growth rate must be supported by accelerated growth in agriculture. The Federal Government of Nigeria has taken a number of policy initiatives with a view to boost agricultural production, provide food security and reduce poverty. These include the liberalization of different agricultural input delivery systems, introduction of measures to involve the private sector in the agricultural sector, launching of special programmes on food security (SPFS), Fadama I, II, III, strategic grain reserves, Agricultural Development Programme (ADP) and increased budgetary allocation to agriculture (Olayemi, 2016).However, to be effective, investments to reduce rural poverty and increase food security must of necessity involve in productivity and income of the farmers especially 
cassava farmers since cassava is one of Nigerians most important stable food. It is generally accepted and recognized as a good source of vital nutrients and energy for the body (FAO, 2015). Therefore cassava farmers must be sufficiently involved if these efforts are to succeed.

\subsection{Economic of Cassava Production}

Cassava (Manihotesculenta) production is vital to the economy of Nigeria as Nigeria is the world's largest producer of the commodity (cassava) followed by Brazil, Indonesia and Thailand. In Africa, other major producers include the Democratic Republic of Congo, Ghana, Madagascar, Mozambique, Tanzania and Uganda. Cassava plays vital role in the food security of the rural economy because of its capacity to yield under marginal soil conditions and its tolerance to drought (Nweke, 2014). The crop is produced in 24 of the country's 36 states. In 2009, Nigeria produced 33 million tonnes, while a decade later, it produced approximately 45 million tonnes, which is almost $19 \%$ of production in the world. The average yield per hectare is 10.6 tonnes. The crop is produced in 24 of the country's 36 states. Cassava production dominates the southern part of the Nigeria, both in terms of area covered and number of farmers growing the crop. Planting occurs during four planting seasons in the various geo-ecological zones. The major states of Nigeria which produce cassava are Anambra, Delta, Edo, Benue, Cross River, Imo, Oyo, and Rivers, and to a lesser extent Kwara and Ondo.

\subsection{ADP Capacity Building and Cassava Farmers' Output}

The Agricultural Development Programme (ADP) in Nigeria were designed in response to the fall in agricultural productivity, and the concern to sustain domestic food supplies, as labour had moved out of agriculture into more remunerative activities that were befitting from the oil boom. ADP capacity building of cassava farmers include new knowledge or technologies related to primary production, processing, marketing of cassava products and commercialization which in turn can positively affect the output, competitiveness, and livelihoods of farmers, income of farmers and others. Cassava farmers' output will increase if the capacity building of farmers and other actors in the agricultural value chain is enhanced to assist them being innovating. Reasons for the neglect of cassava farmers contribution to agricultural development include the small and fragmented nature of their farms, their lack of education, information and technical skills, their numerous domestic chores, societal attitude and traditions in the African society among others.

The establishment of the Agricultural Development Programmes (ADP) in Nigeria ushered in a new era in the history of Nigerian agriculture because for the first time an Agricultural Development Programme (ADP) focused attention on cassava farmers as an important component of agricultural development. While the general aim of the ADP was to raise farm productivity and standard of living of farm families, capacity building oncassava farmers output was to address the peculiar needs of cassava farmers especially in cassava output and welfare of the cassava farmers. This was to harness the total farm agricultural capabilities of cassava famers, so as to build better lives for them, their families, communities, and the nation at large.

\subsection{Theoretical Framework}

The theoretical framework of this study is built on the Cobb-Douglas production function. This theoretical model was applied in extant literature including Igwe and Esonwune(2014), Olubanjo and Oyebanjo (2015), and Izekor and Olumese (2016).In economics, the Cobb-Douglas functional form of production functions is widely used to represent the relationship of output to input. It was proposed by Knut (1851 to 1926) and tested against statistical evidence by Paul Douglas in 1928 (Bao-Hong, 2008). In 1928, Paul Douglas published a study in which they modeled the growth of the American economy during the period 1899 to 1922. They considered a simplified view of the economy in which production output was determined by the amount of labour involved and the amount of capital invested. While there are many other factors affecting economic performance, their model proved to be remarkably accurate.

\subsection{Empirical Review}

Asogwa (2015) evaluated government agricultural policies and effects of resources used in cassava production in Benue State, Nigeria. Data from 360 cassava farmers was analysed using descriptive as well as inferential statistics such as stochastic frontier production function. Results of the field data analysis indicated technical inefficiency decline among cassava farmers in Benue State with the coefficients of improved cassava varieties and improved cassava processing technology as -0.18 and -0.1 respectively. The study concluded that inputs supplied to the farmers through the policy intervention of the government were efficiently used, hence the increased cassava output among the cassava farmers. Furthermore, the policy package in form of improved cassava varieties, improved cassava processing technologies made available to farmers increased the efficiency of their resources-use, hence maximization of their profit. He therefore recommended that policies that encourage input expansion in cassava industry should be 
sufficiently reinforced to bring about much larger increases in cassava production in Nigeria with consequent maximization of the profit of cassava farmers.

Eze, Ibekwe, Onoh and Nwajiuba (2016) undertook a research to isolate the determinants of improved cassava production technologies among farmers in Enugu State, Nigeria. Data collected from a sample of 250 farmers from 10 local government areas of Enugu State were analysed using descriptive statistics and multiple regression analysis. Results shows that cassava production technologies that were at various stages of adoption were use of improved cassava stem cuttings, use of herbicides/pesticides, alternate row/crop geometry in cassava maize intercrop, planting distance, use of fertilizers, machinery, improved storage and processing, and planting angle. The study found the overall mean adoption score and index of 0.96 and 0.191 respectively. The low level of adoption was attributed to the cost of the technologies, their appropriateness, scarcity or non-availability of the extension agents in the study area. The study showed that level of education, age of farmers, farm size, farm income and extension visits were the major determinants of adoption of improved cassava production technologies in the study area.

Economics of improved and local cassava varieties and its welfare effects on producing farmers in Oyo State, Nigeria was the focus of a study by Muhammad-Lawal, Salau and Ajayi (2014). Data from 120 respondents obtained through a three -stage sampling procedure was analysed using descriptive statistics, gross margin and multiple regression analysis. Results of the data analysed showed a gross margin of $\$ 167,733$ and $\$ 114,569$ for farmers using improved and local varieties of cassava respectively. The multiple regression model used showed that farm size, age of farmers, and household size were the variables that explained variation in the output of cassava farmers in the study area. To increase cassava production, the study recommended that policies that ensure farmers access to land and reduction in family size should be adopted.

Productivity analysis of prevalent cassava-based production systems in the large Guinea Savannah using Kwara State as a case study was undertaken by Fakayode, Babatunde and Ajao (2017). Data from 160 cassava producing households were analysed using Total Farm Productivity (TFP) and Ordinary Least Square (OLS) methods. Results showed the cassava/maize enterprise with a TFP of 4.4 level as the most popular and most productive cassava-based enterprise. This was followed by cassava/cowpea, cassava/maize/ guinea corn and cassava/melon systems. To achieve increased yields per cost outlay, the study recommended the enhancement of farmers' access to education and the encouragement of farmers in the cassava copping systems on the use of land and labour saving technologies.

So far, the review of some studies above has actually exposed the necessity of carrying out investigation on ADP capacity building and cassava farmers' output in Anambra State. From the review of related literature, it was clear that studies have been done on general problems associated with cassava productivity and cassava farmers' income, but no known work has been done on ADP capacity building and cassava farmers output in Anambra State. There is an apparent gap in this regard.

\section{Materials and Methods}

\subsection{Research Design}

Descriptive survey design was adopted which aimed at examining the ADP capacity building and cassava farmers' output in Anambra State. This design was adopted for this study because, the purpose of the study is to collect, analyze and report views from cassava farmers concerning ADP capacity building on the output of cassava farmers' in the Anambra State.

\subsection{Area of Study}

The geographic scope within which this study was conducted is Anambra State, Nigeria. Anambra State is one of the States in the Southeastern Nigeria. The state lies within the Igbo heartland of the South Eastern geopolitical zone of Nigeria. It was created on August 27 $7^{\text {th }}, 1991$ with Awka as its capital by General Ibrahim Babangida. Anambra State has a total land area of 4,416 sq kilometers with an estimated population of 4.18 million people (National Population Commission, 2018). Anambra State has 21 local government areas (LGAs) and four agricultural zones (AZs) of Aguata,Awka, Anaocha, and Onitsha.

\subsection{Sample size and Sampling Procedure}

The population of this study comprised all the ADP cassava farmers and non-ADP cassava farmers in Otuocha and Onitsha Agricultural Zone. With membership strength of three hundred and sixty (360) ADP cassava farmers and one hundred and sixty (160) non ADP cassava farmers, making up a total of five hundred and twenty (520) respondents as sourced from Anambra State Agricultural Development Programme (ASADP) Headquarters Awka (2019). 
But to determine the sample size for the study, the researcher adopted A multistage sampling technique of which out of the four (4) Agricultural Zones (AZs) in the state, two (Otuocha and Onitsha) zones were purposively selected because of the high activities of ADP production project and active participation of the cassava farmers. A multistage sampling technique was used to select respondents for this study. The first stage involved a purposive selection of two local government areas (Otuocha and Onitsha agricultural zone)from each of the aforementioned selected AZs based on the predominance of cassava production among the farmers in the study area; (Otuocha AZ: Anambra East and West LGA; Onitsha AZ: Ogbaru and Idemili South LGA).Second stage, two villages were randomly selected using simple random sampling technique from each local government area; (Anambra East LGA: Aguleri and Umueri; Anambra West LGA: Nzam and Ifite-Anam; Ogbaru LGA: Odekpe and Atani; Idemili South LGA: Nnobi and Alor).Third stage, 87 farmers under ADP programme and 87 farmers not under ADP programme were purposively selected from the 8 villages at 11 farmers per village except Nzam where 10 farmers were selected. Thus, giving a total sample size of $\mathbf{1 7 4}$ respondents for the study.

Table 1. The population ADPCFs and non ADPCFs in Otuocha and Onitsha Agricultural Zone, Anambra State

\begin{tabular}{llll}
\hline Agricultural Zone & No. of ADPCFs & No. of non-ADPCFs & No. of Casaava Farmers \\
\hline Otuocha & 165 & 90 & 255 \\
Onitsha & 195 & 70 & 265 \\
Total & $\mathbf{3 6 0}$ & $\mathbf{1 6 0}$ & $\mathbf{5 2 0}$ \\
\hline
\end{tabular}

Source: Anambra State Agricultural Development Programme (ASADP, 2019)

\subsection{Validity and Reliabilityof Instruments}

The measuring instrument used in this study was carefully designed in a systematic way that enabled the researcher elicit opinionated, factual and interpretative information pertinent to the purpose and objective of the study after painstaking and constructive critique from colleagues. The instrument was subjected to test - retest pilot study in order to prove the level of reliability of the research instrument.

A pilot study conducted, copies of the questionnaire for the study were administered to 30 (thirty) respondents in Anambra North Senatorial Zone of Anambra State. The same instrument was administered to the same respondents after two weeks. The coefficient of reliability for their responses was established using Pearson Correlation Coefficient. The Pearson Correlation Coefficient showed a reliability value of 0.751 which was considered high enough for the instrument to be reliable.

\subsection{Method of Data Analysis}

Data were analysed using table of descriptive statistics such as mean and standard deviation through the aid of SPSS on a threshold of 5-point Likert scales. The mean threshold was arrived at using the following formula:

$$
\frac{5+4+3+2+1}{5}=\frac{15}{5}=3.0
$$

The decision rule was to accept any mean score from 3.0 and above, and reject any below that benchmark. The hypothesis was tested using Analysis of Variance (ANOVA). This was tested at $5 \%$ level of significance.

\section{Results and Discussions}

The Table 2 below shows the frequency distribution on demographic factors of the respondents. From the table, it is seen that out of the 174 valid respondents, 101 are male while 73 are female. It also shows that 2 of the respondents are below 18. 64 are between the ages of 18-35. 87 respondents are between the ages of 36-60 while 21 are above 60 . The table also indicated that 87 of the analyzed respondents belong to ADP and 87 are not members of ADP. It is shown from the table that 35 of the respondents have no formal education, 43 have FSLC, 65 have SSCE while 31 have a tertiary degree. The table showed that 77 of the respondents have below 3 hectares of land, 67 have between 3-5 hectares while 30 have 6 hectares and above. 
Table 2. Demographic Factors

\begin{tabular}{|c|c|c|c|c|c|c|}
\hline $\mathbf{N}$ & Biographic & & Options & & & \\
\hline \multirow[t]{2}{*}{1} & Sex & Male & Female & & & Total \\
\hline & Frequency & 101 & 73 & & & 174 \\
\hline \multirow[t]{2}{*}{2} & Age & $<18$ & $18-35$ & $36-60$ & Above 60 & \\
\hline & Frequency & 2 & 64 & 87 & 21 & 174 \\
\hline \multirow[t]{2}{*}{3} & Cooperative Membership & Yes & No & & & \\
\hline & Frequency & 87 & 87 & & & 174 \\
\hline \multirow[t]{2}{*}{4} & Educational Qualification & No Formal Educ. & FSLC & SSCE & Tertiary & \\
\hline & Frequency & 35 & 43 & 65 & 31 & 174 \\
\hline \multirow[t]{2}{*}{5} & Area of Land Owned & $<3$ Hectares & 3-5 Hectares & 6 and above & & \\
\hline & Frequency & 77 & 67 & 30 & & 174 \\
\hline
\end{tabular}

Source: Field Survey, 2019.

\subsection{The Natures of ADP Capacity Building Activities to Cassava Farmers in the Study Area}

The Table 3 below showed the mean values were used for the analysis and the acceptance region is 3 and above while the rejection region is below 3. When the ADP farmers were asked if they have attended workshops organized by the ADP, the mean of their responses was 3.25 showing that they have as the mean is greater than the threshold of 3 . Also, when they were asked if they do go for seminars organized by ADP, the mean of 3.43 showed that they do as it is above the benchmark of 3 . However, the respondents responded negatively when asked if they get involved in apprenticeship arranged by the ADP as shown by a mean 1.87 which is less than the threshold of 3 . When they were asked if training programs were organized for them by the ADP, their responses were cumulatively affirmative as signified by a mean of 3.02. Though, when it was asked if they go for field extension services through the ADP, a mean of 2.20 which is below the threshold of acceptance signifies that they do not cumulatively. In the same vain, they rejected the notion that cassava production skills training were organized for them by the ADP as indicated by a mean of 2.84 . Also, they cumulatively rejected that they do go for cassava processing skills acquisition programs arranged by the ADP as revealed by the mean of 2.67 which is less than 3 . When asked if they do get involved in cassava marketing training, a mean of 2.47 showed that they do not. On whether they were taught strategies to access reliable markets by the ADP, they rejected it as seen by the mean of 2.21. Finally, when they were asked if training on post-harvest management for the best cassava management is organized by the ADP for them, a mean of 2.48 showed that it is not true as the mean is not up to the benchmark of 3 . 
Table 3. Nature of capacity building activities

\begin{tabular}{|c|c|c|c|c|c|c|c|c|c|}
\hline $\mathbf{S} / \mathbf{N}$ & Capacity Building Activity & $\begin{array}{l}\text { VLE } \\
\text { (1) }\end{array}$ & $\begin{array}{l}\mathbf{L E} \\
\text { (2) }\end{array}$ & $\begin{array}{l}\text { MX } \\
(3)\end{array}$ & $\begin{array}{l}\text { HE } \\
\text { (4) }\end{array}$ & $\begin{array}{l}\text { VHE } \\
\text { (5) }\end{array}$ & $\mathbf{N}$ & $\mathbf{X}$ & SD \\
\hline 1. & I have attended workshops organized by the ADP. & 12 & 15 & 12 & 35 & 13 & 283 & 3.25 & 1.296 \\
\hline 2. & I do go for seminar organized by ADP & 10 & 20 & - & 37 & 20 & 298 & 3.43 & 1.369 \\
\hline 3. & I get involved in apprenticeship arranged by the ADP. & 39 & 34 & - & 14 & - & 163 & 1.87 & 1.043 \\
\hline 4. & Training programs are organized for us. & 24 & 19 & 5 & 9 & 30 & 263 & 3.02 & 1.684 \\
\hline 5. & I go for field extension services through the ADP. & 32 & 21 & 19 & 15 & - & 191 & 2.20 & 1.119 \\
\hline 6. & $\begin{array}{l}\text { Cassava production skills training are organized for me } \\
\text { by the ADP. }\end{array}$ & 19 & 21 & 13 & 23 & 11 & 247 & 2.84 & 1.371 \\
\hline 7. & $\begin{array}{l}\text { I do go for cassava processing skills acquisition } \\
\text { programs arranged by the ADP. }\end{array}$ & 33 & 11 & 15 & 8 & 20 & 232 & 2.67 & 1.604 \\
\hline 8. & I get involved in cassava marketing training. & 27 & 21 & 10 & 29 & - & 215 & 2.47 & 1.247 \\
\hline 9. & $\begin{array}{l}\text { I am taught strategies to access reliable markets by the } \\
\text { ADP. }\end{array}$ & 23 & 37 & 13 & 14 & - & 192 & 2.21 & 1.013 \\
\hline 10. & $\begin{array}{l}\text { Training on post-harvest management for the best } \\
\text { cassava management is organized by the ADP. }\end{array}$ & 29 & 20 & 12 & 19 & 7 & 216 & 2.48 & 1.363 \\
\hline
\end{tabular}

Source: Field Survey, 2019.

\subsection{The Differences in Output of ADP and non-ADP Cassava Farmers}

The Table $4 \mathrm{a}$ below showed distribution of responses on the average annual cassava output by ADPCFs and non-ADPCFs. From the table, it is seen that no ADPCFs respondent produced less that 5 bags of cassava on the average annually. It also showed that 10, 32 and 45 ADPCFs produced 5-10, 11-15 and greater than 15 bags of cassava annually respectively. The table also revealed that 9 non-ADPCFs produced less than 5 bags of cassava annually between 2008 and 2018. Also, it indicated that 31, 20 and 27 non-ADPCFs produced 5-10, 11-15 and greater than 15 bags of cassava annually respectively between 2008 to 2018 .

Table 4a. Average annual cassava output

\begin{tabular}{llll}
\hline S/N & Average Annual Cassava Output & ADPCFs & Non-ADPCFs \\
\hline 1 & $\mathbf{5}$ Bags & - & 9 \\
2 & $\mathbf{5 - 1 0}$ & 10 & 31 \\
3 & $\mathbf{1 1 - 1 5}$ & 32 & 20 \\
4 & $>\mathbf{1 5}$ & 45 & 27
\end{tabular}

Source: Field Survey, 2019.

Table $4 \mathrm{~b}$ showed that the cumulative descriptive statistics for annual output of ADPCFs and non-ADPCFs in Anambra State. It showed that ADPCFs have a mean of 36.8851 and a standard deviation of 46.50367 while non-ADPCFs have a mean of 17.3448 and a standard deviation of 18.76837 . 
Table 4b.Descriptive Statistics for Annual Output

\begin{tabular}{lllllllll}
\hline & \multirow{2}{*}{ N } & \multirow{2}{*}{ Mean } & \multirow{2}{*}{ Std. Deviation } & \multirow{2}{*}{ Std. Error } & \multicolumn{2}{c}{$95 \%$ Confidence Interval for Mean } & \multirow{2}{*}{ Minimum } & \multirow{2}{*}{ Maximum } \\
& & & & & Lower Bound & Upper Bound & \\
\hline ADPCFs & 87 & 36.8851 & 46.50367 & 4.98572 & 26.9738 & 46.7963 & 6.00 & 345.00 \\
Non-ADPCFs & 87 & 17.3448 & 18.76837 & 2.01218 & 13.3447 & 21.3449 & 1.00 & 102.00 \\
Total & 174 & 27.1149 & 36.69005 & 2.78147 & 21.6250 & 32.6049 & 1.00 & 345.00 \\
\hline
\end{tabular}

Source: Field Survey, 2019.

\subsection{Test of Hypothesis}

Table 5 showed the ANOVA result for the hypothesis testing for the differences between ADPCFs and non-ADPCFs output. From the result, an ANOVA (F) value of 13.209 was observed signifying that there is a difference exists between ADPCFs and non-ADPCFs output in Anambra state. This difference observed is also statistically significant as the p-value (sig) obtained (.000) is less than .05 level of significance (p-value $<0.05$ ). Therefore, the null hypothesis is rejected in favour of the alternate hypothesis. It was therefore stated that there is a significant difference between ADPCFs output and that of non-ADPCFs.

Table 5. ANOVA

\begin{tabular}{llllll}
\hline & Sum of Squares & df & Mean Square & F & Sig. \\
\hline Between Groups & 16609.195 & 1 & 16609.195 & 13.209 & .000 \\
Within Groups & 216276.506 & 172 & 1257.422 & & \\
Total & 232885.701 & 173 & & & \\
\hline
\end{tabular}

Source: Field Survey, 2019.

\section{Discussion of Findings}

The findings of the study showed that there is a difference between the output of ADPCFs and non-ADPCFs in Anambra state. This was shown in the ANOVA table $4 \mathrm{~b}$ above. This difference could be attributed to the level of capacity building undergone by ADPCFs which non-ADPCFs in Anambra State do not have the privilege to undergo. The finding revealed that ADPCFs go for training, seminars and workshop on how to improve productivity and output which the non-ADPCFs do not undertake. This could be responsible for the differences in mean observed. This finding is consistent with the finding of Muhammad-Lawal, Salau and Ajayi (2014) who did a study on the economics of improved and local cassava varieties and its welfare effects on producing farmers in Oyo State, Nigeria. They found a gross margin of $\$ 167,733$ and $\$ 114,569$ for farmers using improved and local varieties of cassava respectively. This improved varieties of cassava could be a product of belonging to ADP in the state and their improved output which led to improved profit margin.

\section{Conclusion}

It is instructive to conclude from the findings that there is a significant difference in the output of ADPCFs and non-ADPCFs in Anambra State owing to the fact that belonging to ADP is responsible for improved output by the cassava farmers in the program because of the capacity development programs by ADP they attend in the State. In view of the above, it is recommended that cassava farmers in the state that have not yet keyed into ADP in the state needs to do so as there are gains accruable to them by doing this in form of various level of capacity development programs. Attending these programs will increase their output and eventually lead to improved profit margin.

Production resources such as fertilizers, agro chemical, tractor hiring services, processing machines, improved seeds and planting materials, agricultural credit should be given to farmers particularly ADP cassava farmers. There should be targeted delivery to identify cassava farmer groups to ensure that the materials do not get diverted to non-targets. And rural infrastructure such as roads, hospitals, clean water supply, electricity, schools, communication facilities, market infrastructure etc should be provided to make rural life more comfortable in order to improve farm productivity. 


\section{References}

Asogwa, I.A (2015). Analysis of policy issues in technical efficiency of small-scale farmers using stochastic production function with application to Nigerian farmers. Paper prepared for presentation at International Farm Management Association Congress, Wagemngen, Netherlands July 8.

Bao-hong, (2015). Appropriate-Intermediate and modern technologies for rural farmers in Nigeria: Process and Prospects. Farm Management Association of Nigeria conference, 2015,pp 155 - 158.

Berg, W. C. (2016). Raising and sustaining the productivity of small holder farming systems in the Tropics. Agbe Publishing, Alkmaar Holland.

Echeta, N.A. (2016). Socio-economic characteristics of farmers affecting loan repayment in Enugu State of Nigeria. Unpublished M.Sc. Thesis, Department of Agricultural Economics, University of Nigeria, Nsukka.

Etim\&Ukoha, (2016).Adoption of improved cassava varieties and use of improved cassava farm assets under the Cassava Multiplication Programme in Benue State.Proceedings of the 22nd Annual National Conference of the Farm Management Association of Nigeria held at the University of Agriculture Makurdi on the 8-11th September.

Eze, Ibekwe, Onoh, \&Nwajiuba, (2016). Comparative Analysis of Marginal Productivity and Resource use among Cassava Farmers in Edo State. A Mitigating Measure against Food Economics.Proceedings of the 10th Annual National Conference of the Nigerian Association of Agricultural Economists held at University of Abuja on October, 7 th -10 th.

Fakayode, B.,\&Ajao, (2017).Input - Output Relationship and Resource Use Efficiency in Cassava Production in Jama"a L. G. A. of Kaduna State.Proceedings of the 10th Annual Conference of Nigeria Association of Agric Economics, 7 - 10th October held at University of Abuja.

Fan, R. \&Rosegrant, N. (2014).Methods for studying collective action in rural development, CAPRi Working Paper. Washington D.C.: International Food and Policy Research Institute

Food \& Agriculture Organization.(2015).Agricultural Investment and Productivity in Developing Countries.FAO Economics and Social Development Paper No. 148. FAO Document Repository.

Igwe\&Esonwune, (2014). An X-ray of Nigeria's agricultural sector exports and gross domestic product under diverse exchange rates policies: 1960-2002. Journal of Economics and Allied Fields, 2(2).

Izekor\&Olumese, (2016).Economic analysis of cassava-based cropping systems in crude oil producing area: A case study of Rivers State, Nigeria(Unpublished Ph.D dissertation. Department of Agricultural Economics, Ahmadu Bello University, Zaria).

Kamajou, (2014).Factors Constraining on-the-Job Training and Farm Visits of Extension Agents in Enugu State.Journal of Education and Vocational Studies, 1(61).

Muhammad, Lawal, Salau,\&Ajayi, (2014).Economics of improved and local varieties of cassava among farmers in Oyo State, Nigeria.Ethiopian Journal of Environmental Studies and Management, 5(2).https://doi.org/10.4314/ejesm.v5i2.10

Nnadi, M. A. (2014). Impact of Small-Scale Irrigation technologies on Crop Production by Fadama users in Niger State, Nigeria.Proceedings of the 10th Annual Conference of Nigeria Association of Agric Economics, 7 - 10th October held at University of Abuja.

Nweke, L. (2014). "The Place of Agriculture in Economic Development".Agriculture in Economic Development. McGraw - Hill.

Nwosu, C. S. (2014). Comparative Economics of Resource Use by ADP and Non-ADP Cassava Farmers in Orlu Agricultural Zone of Imo State, Nigeria.Proceedings of the 39th Annual Conference of Agricultural Society of Nigeria, University of Benin, October 9th - 13th, pp $1-4$.

Okafor, P. S. (2016). Farmers' Production Behaviour and Agricultural Labour productivity in Nigeria: Social Change. Journal of the Council for Social Development, 16(4), 12-19.

Okolo, O. (2014). Efficiency of resource -use in cassava production in Kogi State, Nigeria: Implications for food security and environmental degradation. Journal of Environmental Extension, 4, 13-17.

Olayemi, S. O., \& Heady, E. O. (2016). Introduction to Agricultural Production Economics. Ibadan University Press, Ibadan. 
Olubanjo, \& Oyabanjo, J. O. (2016). Introduction to Agricultural Marketing and Prices: Principles and Application. Living book series, GU publications Abuja 115pp.

Olukunle, Y. (2013). Impacts of technology and structural change on Agricultural economy, rural communities and the environment. American Journal of Agricultural Economics, 67(5), 1158-1163. https://doi.org/10.2307/1241392

Rasheed, T. M. (2014). Technical Efficiency of Poultry Egg Production in Ogun State.A Data Envelopment Analysis (DEA) Approach. International Journal of Poultry Science, 6(9), 622-629. https://doi.org/10.3923/ijps.2007.622.629

Senauer, P. O. (2016). Cereal Crop Productivity in Developing Countries: Past Trends and Future Prospects. Economics, Working Paper.Available in http://impact.cgiar.org/pdf/284.pdf.Accessed June 11, 2016.

United Nations, (2016). Economic and Social Council: Definition of basic concepts and terminologies in governance and public administration.Committee of Experts on Public Administration, 5th session, New York, 27-31 March 2016.

Uzor, E. J. (2015). Application of stochastic production frontier in the estimation of cassava-based farms in Akwalbom state Nigeria. Agric. J., 2(6), 731-735.

Wheeler, D. (2017). Transactions costs and agricultural productivity: Implications of isolation for rural poverty in Madagascar. MSSD Discussion Paper 56. Washington: International Food Policy Research Institute

World Bank. (2014). World Development Report 2018: Agriculture for Development. Washington D.C. 